ALTRUIS, e-ISSN 2620-5513, p-ISSN 2620-5505, Vol. 1, No. 1, April 2018

Abdimas Altruis : Jurnal Pengabdian Kepada Masyarakat

http://e-journal.usd.ac.id/index.php/ABDIMAS

Universitas Sanata Dharma, Yogyakarta

\title{
Pembangunan dan Implementasi Sistem Informasi Bank Darah di PMI dan RSUD Muntilan Kabupaten Magelang
}

\author{
Agnes Maria Polina ${ }^{1}$, Fenty ${ }^{2}$ \\ ${ }^{1}$ Program Studi Teknik Informatika, Universitas Sanata Dharma \\ ${ }^{2}$ Program Studi Farmasi, Universitas Sanata Dharma \\ Email: ${ }^{1}$ A.M.Polina@usd.ac.id \\ https://doi.org/10.24071/altruis.2018.010104
}

\begin{abstract}
Blood bank administration in PMI, Magelang Regeency is still managed manually, which prevents hospitals from accessing information on blood stock quickly. Hospitals can access information about blood stock by phone only. Such a manual system could be a problem in delivering an excellent service. Therefore, a solution is required to improve the quality of services delivered by PMI. The use of information technology called Blood Bank Information System (SIBD/Sistem Informasi Bank Darah) is promising to improve the quality of services of the PMI. The SIBD helps the hospital to improve time efficiency in the blood demand process. There were several activities which have been completed, i.e.: 1) Developing SIBD at PMI of Magelang Regency; 2) Improving hardware facilities at PMI of Magelang Regency and RSUD Muntilan, including the procurement of computer hardware, modem, and Internet access for each institution; 3) Training on the use of SIBD for both PMI and hospital staff. The results wrer: 1). SIBD at PMI which is linked to RSUD Muntilan and other hospitals for blood supply information and online order; 2) Blood Bank Administration Database which can improve quality of service; 3) capability of PMI and RSUD Muntilan, Magelang Regency staff in utilizing SIBD to improve services to patients.
\end{abstract}

Keywords: Bank Darah, PMI, Sistem Informasi Bank Darah

\section{PENDAHULUAN}

\section{Analisis Situasi}

Pelayanan yang cepat dan tepat dalam penyediaan darah dapat menolong banyak jiwa. PMI memegang peranan penting yaitu dalam hal: 1) melayani permintaan darah, 2) menyediakan darah yang meliputi pengambilan darah, pengolahan darah, penyimpanan darah, dan 3) mendistribusikan darah kepada pasien. Namun yang terjadi pada banyak PMI termasuk PMI KabupatenMagelang, pengelolaan blood bank (bank darah) masih dilakukan secara manual.

Berdasarkan observasi dan wawancara dengan kepala serta staf di PMI Kabupaten Magelang, diketahui jumlah rumah sakit yang dilayani berjumlah 10 rumah sakit (yang terbesar adalah RSUD Muntilan), dengan permintaan 5.110 kolf (kantong darah) per tahun, jadi rata-rata terdapat 14 permintaan darah per hari. Jumlah stafyang melayani terdiri dari 1 staf administrasi, 5 staf operasional, 1 dokter pelaksana, dan 1 orang dokter kepala (direktur). Dengan jumlah 5 staf operasional, pelayanan cukup memadai namun timpang bila dibandingkan dengan pelayanan administrasi yang hanya dilayani 1 orang staf yang mana semua administrasi permintaan darah, administrasi pengambilan darah, administrasi pengolahan darah, administrasi penyimpanan darah dan administrasi pendistribusian darah semuanya masih dilakukan secara manual. Akibatnya pelayananan masih lambat, yaitu rata-rata 1 s/d 2 jam dari proses permintaan darah sampai pendistribusian darah kepada keluarga pasien. Bila stok darah kosong, maka dapat memakan waktu sampai 6 jam dari proses permintaan sampai diserahkannya darah kepada keluarga pasien.

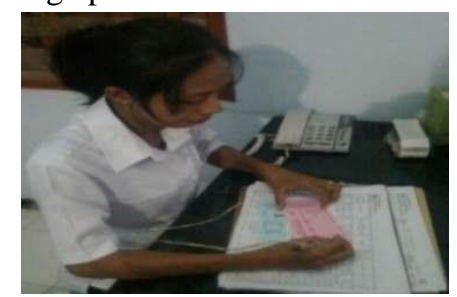

Gambar 1. Pelayanan administrasi permintaan darah di PMI Kabupaten Magelang dilakukan secara manual.

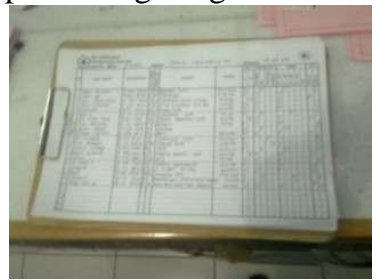

Gambar 2. Daftar Catatan Permintaan Darah 
Di sisi lain, perkembangan teknologi informasi sudah sedemikian berkembang pesat. Pengguna internet di Indonesia sudah mencapai 82 juta orang pada tahun 2013, naik 25 juta dalam setahun terakhir (sumber: www.apjii.or.id) sehingga menjadi 107 juta orang pada tahun 2014, dengan mayoritas penggunaan untuk jejaring sosial seperti facebook 28\%, email 25\%, web browsing $15 \%$. Namun belum banyak digunakan untuk pelayanan di bidang kesehatan (sumber: $\underline{\text { www.internetworldstats.com). }}$.

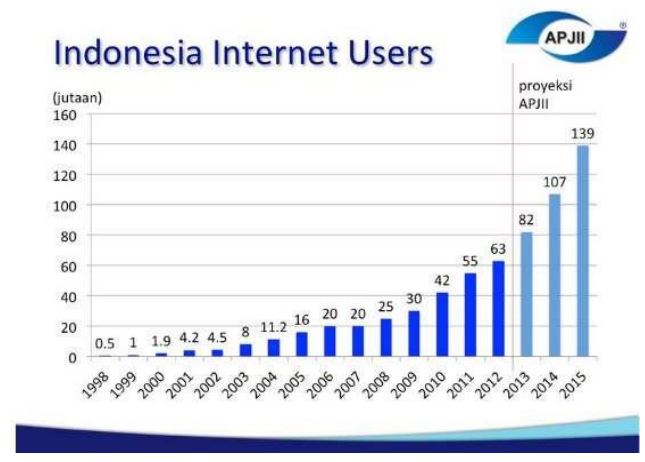

Gambar 3. Profil Pengguna Internet di Indonesia (sumber: www.apjii.or.id)

\section{Permasalahan Mitra}

Dari analisis situasi tersebut, terdapat beberapa permasalahan yang dihadapi PMI Kabupaten Magelang maupun pihak Rumah Sakit Umum Daerah (RSUD) Muntilan yaitu :

a. Proses administrasi berlangsung lambat meliputi: 1) permintaan darah, 2) pengolahan darah, dan 3) pendistribusian darah kepada keluarga pasien.Pihak rumah sakit tidak dapat segera mengetahui jenis golongan darah pada stok darah yang tersedia dan berapa kolf yang tersedia di PMI. Media telepon merupakan satu-satunya sarana yang digunakan oleh rumah sakit untuk mendapat informasi. Demikian pula PMI KabupatenMagelang juga menggunakan telepon untuk menyampaikan informasi kepada pihak rumah sakit. Akibatnya pihak rumah sakit juga lambat memberi informasi kepada keluarga pasien apakah jenis darah yang dibutuhkan tersedia di PMI Kabupaten Magelang ataukah keluarga pasien harus mencari donor.

b. Jumlah dan jenis perangkat keras maupun perangkat lunak komputer yang tersedia kurang memadaiuntuk membantu pengolahan blood bank di PMI KabupatenMagelang. Demikian pula di RSUD Muntilan belum tersedia perangkat komputer yang memadai untuk digunakan melihat stok darah maupun melakukan permintaan darah ke PMI KabupatenMagelang.

c. Terbatasnya pengetahuan dan ketrampilan staf administrasi PMI maupun staf RSUD Muntilan dalam menggunakan teknologi informasi untuk meningkatkan administrasi pelayanan permintaan dan distribusi darah secara cepat, tepat, dan akurat.

\section{Kajian Teoritik}

Permasalahan di lapangan ditemukan sebagian besar rumah sakit tidak memiliki manajemen pelayanan darah, sehingga sering terjadi kesulitan dalam upaya memperoleh darah. Hal yang penting adalah belum adanya sistem koordinasi pelayanan darah antara Unit Donor Darah (UDD) PMI dan Bank Darah Rumah Sakit (BDRS) serta masyarakat sebagai pendonor darah. Sistem koordinasi yang belum baik ini mengakibatkan kualitas pelayanan darah menjadi kurang baik, masyarakat sulit mendapatkan darah yang aman dan tepat waktu (Syafei, 2009).

Hasil survei yang dilakukan pada Juli 2013 menunjukkan bahwa website PMI di ibu kota propinsi yaitu PMI Jakarta (www.pmidkijakarta.or.id), PMI Yogyakarta (www.pmi-yogya.org), PMI Semarang (www.uddpmisemarang.com), PMI Surabaya (www.pmiutdsby.org), PMI Bandung (www.fourthsuare/pmi-kota-bandung) juga menunjukkan belum adanya Sistem Informasi Bank Darah PMI yang mengintegrasikan antara PMI dan rumah sakit.

Yoga (2011) menyatakan semakin tinggi peranan teknologi informasi, semakin tinggi pula kepuasan pasien melalui peningkatan kualitas layanan.

\section{Tujuan dan Manfaat Kegiatan}

Tujuan kegiatan ini adalah: 1) Melakukan Updating ipteks di PMI maupun RSUD Muntilan Kabupaten Magelang, 2) Membentuk basis data administrasi bank darah yang terorganisir dan teratur, 3) Meningkatkan kualitas pelayanan administrasi permintaan darah secara lebih cepat, tepat, dan akurat, 4)Secara umum meningkatkan penggunaan teknologi informasi di bidang pelayanan kesehatan. Manfaat program ini diharapkan sistem ini dapat membantu menurunkan angka kematian akibat terlambatnya penyediaan darah kepada pasien serta menjadi contoh/prototype bagi PMI maupun rumah sakit di kabupaten lain.

\section{METODE PELAKSANAAN}

Dari analisis situasi dan permasalahan mitra seperti tersebut di atas, solusi yang diberikan yaitu dengan cara membangun Sistem Informasi Bank Darah PMI Kabupaten Magelangyang bertujuan agar pertukaran informasi dapat dilakukan secara mudah, cepat, dan akurat. Sistem ini akan mengintegrasikan antara PMI Kabupaten Magelang, RSUD Muntilan, dan anggota pendonor sehingga stok darah dan permintaan darah 
dapat diketahui melalui media yang mudah diakses oleh masyarakat yaitu melalui website. Secara garis besar, ada 3 tahap langkah utama yang dilakukan yaitu :

1. Pembangunan Sistem Informasi Bank Darah (SIBD) PMI Kabupaten Magelang, yang terdiri dari beberapa tahap sebagai berikut :
a. Identifikasi masalah yang dihadapi user/pengguna sistem (PMI \& RSUD Muntilan).
b. Identifikasi kebutuhan PMI \& RSUD Muntilansebagai user/pengguna.

c. Analisa Sistem : menganalisa bentuk SIBD yang paling sesuai untuk kebutuhan user (PMI maupun RSUD Muntilan).
d. Disain Sistem : mendisain SIBD yang sesuai dengan hasil analisa sistem

e. Pembuatan Program Sistem Informasi Bank Darah Berbasis Web

f. Alpha Test Sistem : test quality control untuk menjamin program bebas dari kesalahan.

2. Pembenahan sarana perangkat keras di PMI Kabupaten Magelang meliputi : pengadaan satu perangkat keras komputer, modem, dan penyediaan akses internet.

Pembenahan sarana perangkat keras di RSUD Muntilan meliputi : pengadaan satu perangkat keras komputer, modem, dan penyediaan akses internet.

3. Pelatihan penggunaan ipteks (Sistem Informasi Bank Darah Berbasis Web) untuk staf PMI Kabupaten Magelangmaupun staf RSUD Muntilan. Tim pengabdi berperan sebagai : (1) System Analyst yaitu 1 orang ahli Patologi Klinik Bank Darah)yang bertugas menganalisa proses bank darah apakah sudah pada jalur yang benar dan optimal.(2) System Analyst yaitu 1 orang ahli Sistem Informasiyang bertugas menganalisa proses bank darah secara manual untuk diubah dapat diimplementasikan secara terkomputerisasi. (3) System Designer yang bertugas mendisain user interface, input, output, database, dan technology Sistem Informasi Bank Darah.(4) Project Manager yang bertugas memimpin proyek pembangunan Sistem Informasi Bank Darah sampai dengan implementasinya. (5) Instruktur yang bertugas memberi pelatihan penggunaan Sistem Informasi Bank Darah di PMI dan RSUD.

Mitra yang terlibat adalah sebagai berikut: (1) PMI Kabupaten Magelang yang beralamat di Jl. Kartini No.26 Muntilan, Kabupaten Magelang. Mitra ini melibatkan 8 orang terdiri dari Ketua PMI, sekretaris PMI, dokter Kepala UDD, dan 5 staf UDD PMI. (2) RSUD Muntilan Kabupaten Magelang yang berlokasi di Jl. Kartini No. 13 Muntilan, Kab.Magelang. Mitra ini melibatkan 7 orang terdiri dari dokter Kepala Bank Darah, Kabag IT RSUD, dan 5 staf BDRS.

Lama pelaksanaan proyek ini adalah 11 bulan (Februari s/d Desember 2013).

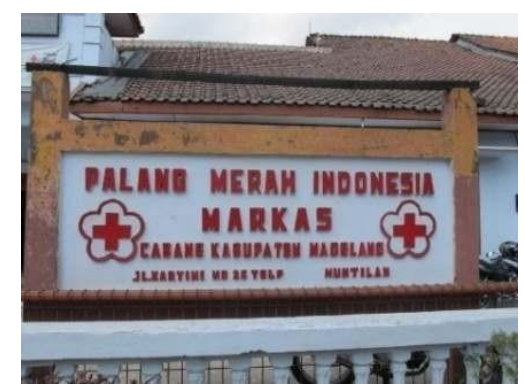

Gambar 4. Markas PMI Kabupaten Magelang

\section{HASIL DAN PEMBAHASAN}

Secara rinci, terdapat 5 tahap kegiatan yang telah dilakukan, yaitu :

1. Pembangunan Sistem Informasi Bank Darah (SIBD) PMI Kabupaten Magelang Berbasis Web (Februari s/d Agustus 2013).

2. Sosialisasi pemanfaatan SIBD untuk meningkatkan pelayanan PMI kepada Direktur PMI, Dokter Pelaksana, staf PMI, Direktur dan staf RSUD Muntilan (25 Juli 2013).

3. Implementasi SIBD (September s/d Oktober 2013).

4. Pelatihan Penggunaan SIBD kepada PMI Kabupaten Magelang (September s/d Desember 2013)

5. Pelatihan Penggunaan SIBD kepada RSUD Muntilan(September s/d Desember 2013)

\section{Pembangunan Sistem Informasi Bank Darah PMI Kabupaten Magelang Berbasis Web} antara lain :

Hal-hal yang telah dilakukan pada tahap ini

a. Identifikasi masalah yang dihadapi user/pengguna sistem (PMI \& RSUD) secara lebih mendalam.

b. Identifikasi kebutuhan PMI \& RSUD Muntilan sebagai user/pengguna (melalui interview, observasi, dan pertemuan dengan para stafkedua belah pihak).

c. Analisa Sistem : menganalisa bentuk SIBD yang paling sesuai untuk kebutuhan user (PMI maupun RSUD Muntilan).

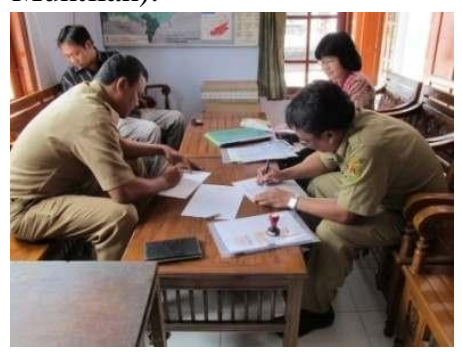

Gambar 5. Tahap Analisa Sistem SIBD - Pertemuan dengan Kepala dan staf UDD PMI Magelang 
d. Mendesain Sistem : mendesain user interface, input, output, database, dan technology SIBD yang sesuai dengan hasil kesepakatan analisa sistem.

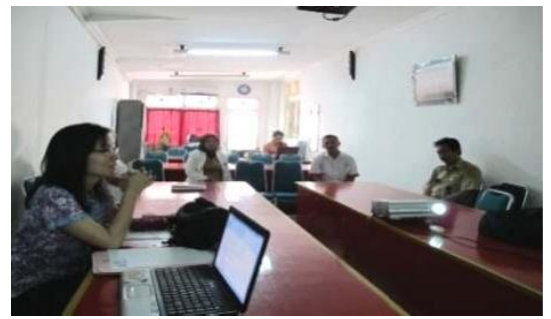

Gambar 6. Tahap Desain SIBD - Pertemuan dengan

Kepala dan staf UDD PMI Kabupaten Magelang serta Kepala dan staf Bank Darah RSUD Muntilan.

e. Pembuatan program/ perangkat lunak SIBDBerbasis Web

f. Alpha Test Sistem : test quality control untuk menjamin program bebas dari kesalahan.

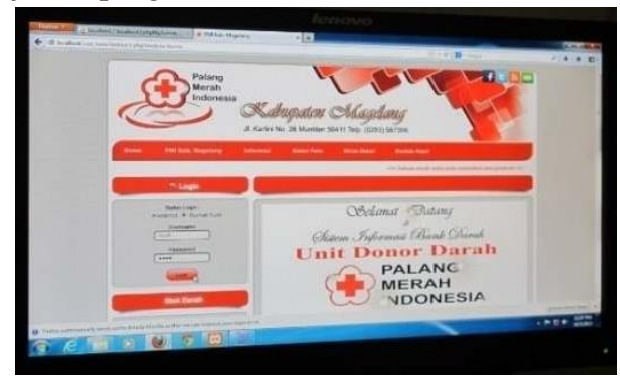

Gambar 7. Hasil Tahap Pembuatan Program (coding) SIBD dan Alpha Test Sistem

Hasil dari tahap Pembangunan Sistem adalah : tersedia Perangkat Lunak SIBD PMI Kabupaten Magelang, yang memiliki kemampuan :

a. Halaman Pendonor

Hak akses diberikan pada pendonor untuk : (1) melihat data dirinya; (2) melihat history donor darah yang telah dilakukan; (3) mengubah data dirinya; (4) mengubah password.

b. Halaman Rumah Sakit

Hak akses diberikan pada staf rumah sakit untuk: (1) tambah, ubah, hapus data pasien dirawat yang membutuhkan permintaan darah; (2) tambah, ubah, hapus data dokter penanggung jawab permintaan darah; (3) tambah, ubah, hapus data permintaan darah; (4) mencetak surat permintaan darah untuk pengambilan darah ke PMI; (5) melihat informasi stok darah yang ada di PMI; (6) mengubah password.

c. Halaman Petugas UDD PMI

Hak akses staf PMI dapat melakukan : (1) lihat data permintaan darah dari rumah sakit; (2) tambah, ubah, hapus data permintaan darah; (3) lihat, tambah, ubah, hapus data cross match permintaan darah; (4) lihat, tambah, ubah, hapus data hasil lab; (5) lihat data darah yang siap didistribusikan (data yang layak diberikan kepada pasien); (6) lihat, tambah, ubah, hapus data pendonor; (7) lihat data diri pendonor dan history donor darah; (8) lihat, tambah, ubah, hapus data donor darah.

d. Halaman Admin PMI

Hak akses admin PMI untuk : (1) lihat, tambah, ubah, hapus data staff petugas PMI; (2) lihat, tambah, ubah, hapus data admin dan ketua; (3) lihat, tambah, ubah, hapus data berita dan agenda PMI.

e. Halaman Ketua PMI

Hak akses ketua PMI dapat melihat : (1) laporan pendonor yang ada di PMI Kab. Magelang; (2) laporan permintaan darah per periode; (3) laporan donor darah dalam suatu periode.

\section{Tahap Sosialisasi SIBD untuk meningkatkan pelayanan PMI dan RSUD}

Pertemuan sosialisasi berisi:

a. Penjelasan peran, tujuan, manfaat SIBD untuk meningkatkan pelayanan permintaan darah secara cepat, tepat, dan akurat.

b. Penggunaan SIBD untuk pemesanan darah ke PMI, pengolahan data pendonor,pengolahan permintaan darah, penyimpanan data darah, dan distribusi darah ke pasien.

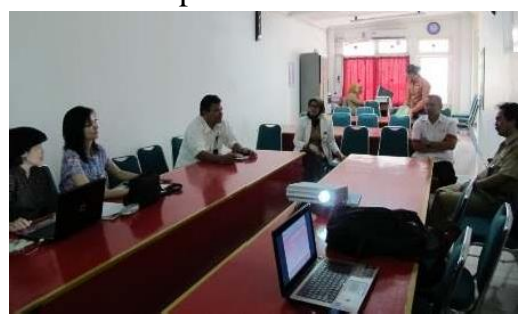

Gambar 8. Sosialisasi kepada Direktur, Dokter Pelaksana, dan staf PMI Kabupaten Magelang, serta Direktur dan staf RSUD Muntilan

Hasil pertemuan sosialisasi menunjukkan bahwa:

a. Terjadi peningkatan pengetahuan bagi staf PMI tentang peran SIBD untuk membantu meningkatkan efisiensi pelayanan di PMI.

b. Staf PMI mendapatkan gambaran penggunaan SIBD untuk pengolahan data pendonor, pemesanan darah, pengolahan permintaan darah, penyimpanan darah, dan distribusi darah.

c. Staf RSUD mendapat gambaran cara pemesanan darah melalui SIBD

d. Terdapat kesepakatan antara PMI Kabupaten Magelang dan RSUD Muntilan untuk tahap implementasi.

\section{Tahap Implementasi dan Instalasi SIBD di PMI Kabupaten Magelang dan RSUD Muntilan} Pada tahap ini telah dilakukan :

a. Instalasi 1 set perangkat keras komputer dan juga instalasi Perangkat Lunak SIBD di PMI Kabupaten Magelang. 
b. Beta Test Sistem (pengujian apakah Sistem Informasi Bank Darah sudah sesuai dengan kebutuhan user)

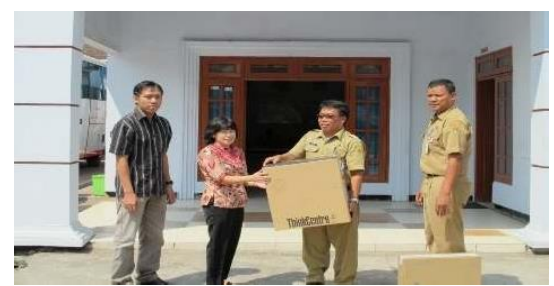

Gambar 9. Serah terima 1 set komputer ke PMI Kabupaten Magelang

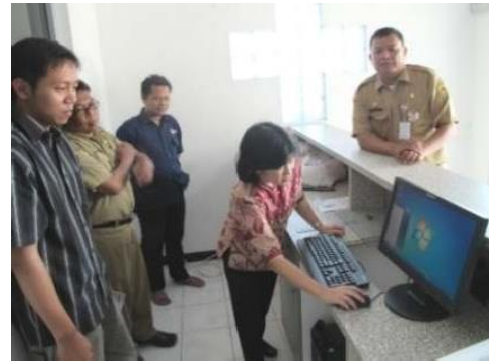

Gambar 10. Instalasi hardware dan software SIBD di PMI Kab. Magelang

c. Instalasi Perangkat keras juga dilakukan di RSUD Muntilan.

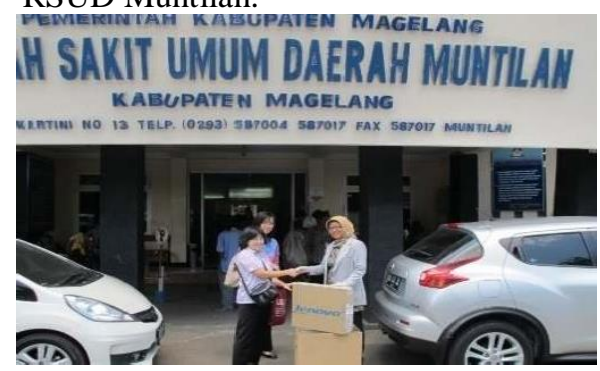

Gambar 11. Serah terima 1 set komputer kepada RSUD Muntilan

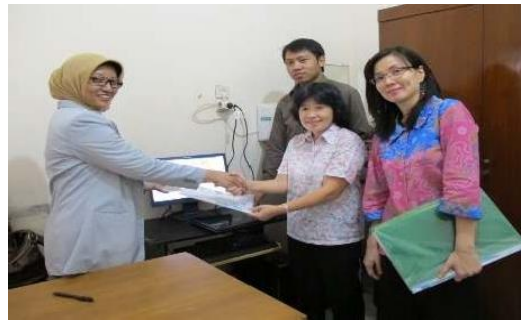

Gambar 12. Instalasi hardware dan software SIBD di RSUD Muntilan

\section{Pelatihan Penggunaan SIBD di PMI Kab. Magelang}

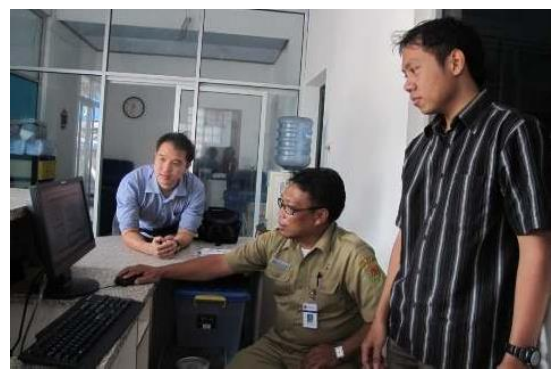

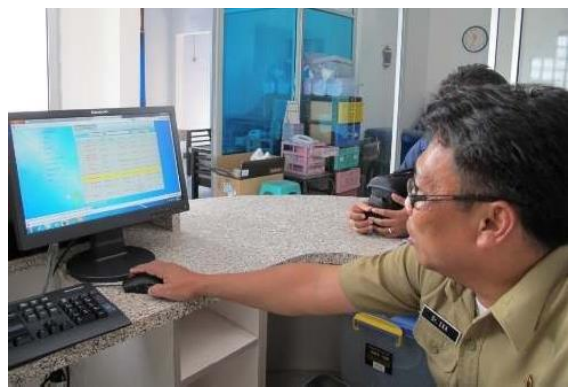

Gambar 13. Pelatihan Penggunaan SIBD di PMI Kabupaten Magelang

Hasil Pelatihan SIBD menunjukkan bahwa para staf UDD PMI Magelang dapat melakukan proses untuk :

a. Mengakses permintaan darah menggunakan SIBD.

b. Mengupdate pemesanan darah dari RSUD

c. Melakukanvalidasi (cross match) data darah yang akan didistribusikan/ diserahkan ke keluarga pasien.

d. Menyimpan data darah hasil pemeriksaan lab, penyimpanan darah.

e. Mengolah data pendonor.

\section{Pelatihan Penggunaan SIBD di RSUD Muntilan}

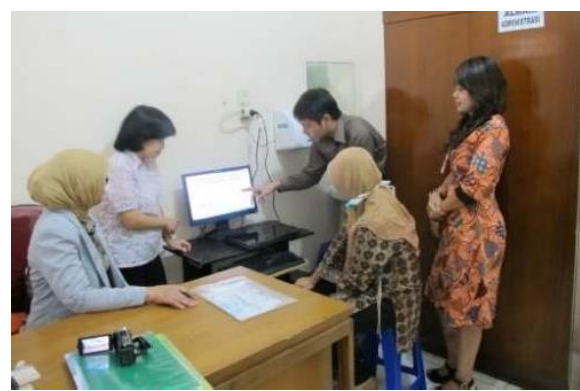

Gambar 14. Pelatihan Penggunaan SIBD di RSUD Muntilan

Hasil Pelatihan SIBD ini menunjukkan bahwa staf Laboratorium Patologi Klinik RSUD Muntilan dapat melakukan proses:

a. Melihat stok darah di PMI Kabupaten Magelangmelalui SIBD.

b. Memesan darah melalui SIBD

c. Memantau apakah darah sudah diterima oleh keluarga pasien.

\section{KESIMPULAN}

Kegiatan ini telah berhasil diimplementasikan dengan baik. Saat ini sudah terbentuk basis data administrasi bank darah yang terorganisir dan teratur, tersedia Sistem Informasi Bank Darah PMI Kabupaten Magelang, dan sudah tersedia sarana perangkat komputer beserta akses internet di PMI Kabupaten Magelang maupun RSUD Muntilan.

Hasil implementasi SIBD PMI Kabupaten Magelang menunjukkan bahwa sistem ini telah dapat 
digunakan untuk : (1). Pihak rumah sakit dapat melihat stok darah dan memesan secara online ke PMI. (2). PMI dapat dengan cepat memproses permintaan darah dan melakukan validasi darah (cross match) yang akan diserahkan ke keluarga pasien. (3). Bagi masyarakat umum dapat memantau ketersediaan darah di PMI Kabupaten Magelang dari mana pun dan kapan pun melalui website SIBD. 94). PMI dapat mengolah data pendonor, data hasil pemeriksaan lab, dan stok penyimpanan darah. 95). Pendonor dapat mengakses riwayat donor darah dan mendapat reminder bila sudah diperbolehkan saat mendonor kembali. 6). Kepala PMI memperoleh berbagai macam jenis laporan sesuai kebutuhan laporan baik laporan untuk internal maupun eksternal ke PMI Pusat.

\section{UCAPAN TERIMAKASIH}

1. Direktorat Riset dan Pengabdian Masyarakat

Kementerian Riset, Teknologi, dan Pendidikan Tinggi yang telah mendanai kegiatan ini melalui Program Hibah Ipteks bagi Masyarakat (IbM).

2. F.X. Adhi Nugroho, S.Kom sebagai programmer Sistem Informasi Bank Darah.

\section{DAFTAR REFERENSI}

Jeffrey L Whitten, Lonnie D Bentley, Victor M. Barlow, (2004).Information System Analysis \& Design Methods,Sixth Edition, Irwin.

Syafei, C., (2009). Pelayanan Darah Belum Optimal. Diakses 1 Agustus 2013 dari http:// www. waspada.co.id/index.php.

Yoga, T.A. (2011). Peranan Teknologi Informasi dan Kualitas Layanan Terhadap Kepuasan Pasien Rawat Inap (Studi pada PT. Perkebunan Nusantara XI Persero Rumah Sakit LAVALETTE Malang), Magister Manajemen Pascasarjana Fakultas Ekonomi Universitas Brawijaya. Diakses 17 November 2014 dari http:// elibrary.ub.ac.id/

-, Pengguna Internet di Dunia, Web Site Internet World Statisticwww.internetworldstats.com

-, Pengguna Internet di Indonesia, Web Site Biro Pusat Statistik www.bps.go.id

\section{LAMPIRAN}

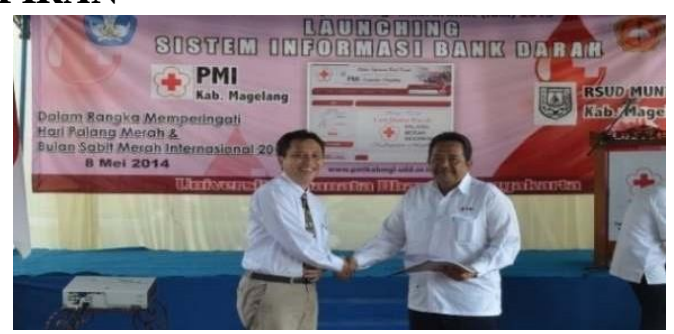

Gambar 15. Peluncuran SIBD oleh Rektor USD dan

Ketua PMI Kabupaten Magelang pada tanggal 8 Mei 2014

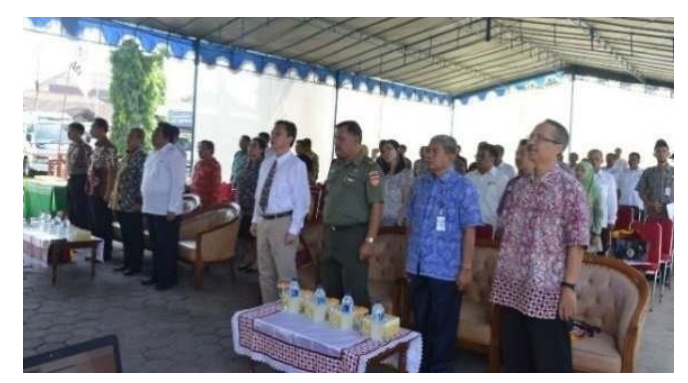

Gambar 16. Peluncuran dihadiri oleh Ketua PMI Jawa Tengah

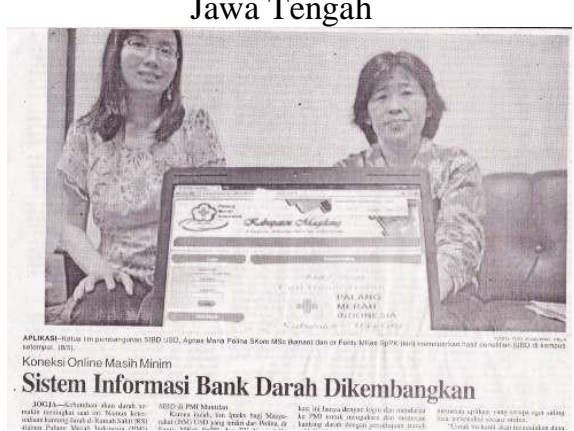

Gambar 17. Berita Peluncuran SIBD di harian Kedaulatan Rakyat

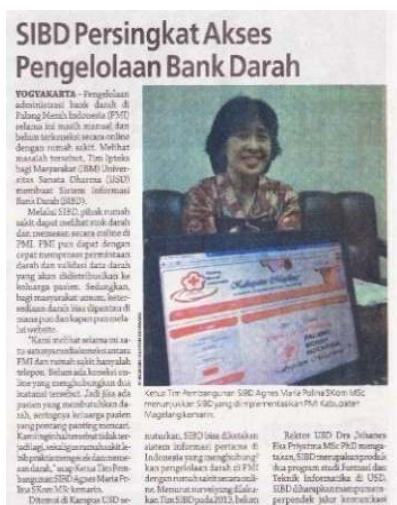

Gambar 18. Berita Peluncuran SIBD di harian SINDO (Seputar Indonesia) 